\title{
MUSLIM PERSONAL LAW AND THE MEANING OF "LAW" IN THE SOUTH AFRICAN AND INDIAN CONSTITUTIONS ${ }^{1}$
}

\author{
Christa Rautenbach \\ B Juris, LLB, LLM. Senior Lecturer in Private Law at the PU vir CHO.
}

\section{$1 \quad$ Introduction}

Two percent of the total population of South Africa consists of Muslims ${ }^{2}$ who follow a practice which may be referred to as Muslim personal law. Although section 15 of the Constitution of the Republic of South Africa ${ }^{3}$ recognises religious freedom and makes provision for the future recognition of other personal law systems, Muslim personal law is, at this stage, not formally recognised in terms of South African law. Since Muslim personal law receives no constitutional recognition the question may be asked whether the 1996 Constitution, and in particular the Bill of Rights as contained in chapter 2 of the 1996 Constitution, is applicable to "non-recognised" Muslim personal law. The answer to this question depends to a large extent on the meaning of "law" as contained in section 8 and item 2 of schedule 6 of the 1996 Constitution. ${ }^{4}$

In order to analyse the meaning of "law" as contained in the 1996 Constitution, it is important to determine how the 1996 Constitution is to be interpreted. Section 39 provides important guidelines and lays down that the "values that underlie an open and democratic society based on human dignity, equality and freedom" must be promoted. $^{5}$ Furthermore, international law must and foreign law may be considered ${ }^{6}$ and, finally, the "spirit, purport and objects of the Bill of Rights" must be promoted. ${ }^{7}$

1 The financial assistance of the NRF (previously the HSRC) is hereby acknowledged with gratitude.

2 Central Statistical Services Report 03/01/22(91) Population Census 1991.

3 Constitution of the Republic of South Africa 108 of 1996. Hereinafter referred to as the 1996 Constitution.

4 See $\S 2$.

5 Section 39(1)(a).

6 Sections 39(1)(b) and (c).

7 Section $39(2)$. 
In this note the meaning of "law" as contained in the 1996 Constitution will be compared with the meaning of "law" as contained in the Constitution of India, which came into operation on 26 January $1950 .^{8}$ Such comparison will be done with due consideration of the warning expressed in Park-Ross $v$ Director, Office for Serious Economic Offences, ${ }^{9}$ namely that any comparison with foreign case law

... should be done with circumspection because of the different contexts within which other constitutions were drafted, the different social structures and milieu existing in those countries as compared with those in this country, and the different historical backgrounds against which the various constitutions came into being. ${ }^{10}$

\section{The meaning of "law" in the South African constitutions}

\subsection{The meaning of "law" and the 1993 Constitution}

The commencement of the Constitution of the Republic of South Africa ${ }^{11}$ on 27 April 1994 marks the beginning of a new constitutional dispensation for South Africa. Section 7(2) of the 1993 Constitution made provision for the application of a Bill of Rights to "all law in force". The constitutional court in Du Plessis v De Klerk ${ }^{12}$ held that the phrase "all law in force" referred to the common law and statute law. Since Muslim personal law is not recognised in terms of South African common law or statute law, it may be argued that Muslim law is not "all law in force", and that it was, therefore, not subject to the provisions of the Bill of Rights as contained in the 1993 Constitution. It must be kept in mind, however, that Du Plessis v De Klerk did not deal with the application of the Bill of Rights on other personal law systems, such as Muslim personal law.

\section{$2.2 \quad$ The meaning of "law" and the 1996 Constitution}

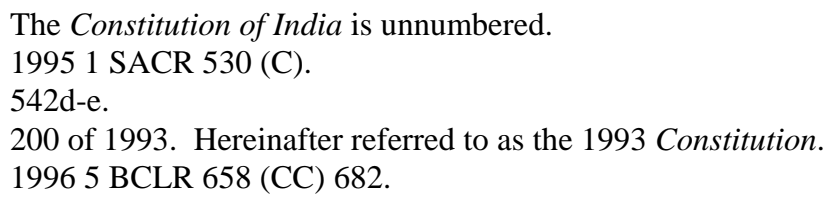

P E R 1999 Vol 2 http://www.puk.ac.za/lawper/ 
The 1993 Constitution was repealed by the 1996 Constitution that commenced on 4 February 1997. The phrase "law in force" as contained in section 7(2) of the 1993 Constitution was omitted in the 1996 Constitution. Section 8(1) of the 1996 Constitution refers only to "all law" and reads:

The Bill of Rights applies to all law, and binds the legislature, the executive, the judiciary and all organs of state. ${ }^{13}$

The first question that comes to mind is whether the omission of the phrase "in force" changes the applicability of the Bill of Rights to non-recognised Muslim personal law. On the face of it, the answer appears to be in the negative. Writers such as Burns ${ }^{14}$ and De Waal, Currie and Erasmus ${ }^{15}$ argue that the Bill of Rights applies to legislation, common law and customary law. ${ }^{16}$ If such a viewpoint is to be followed, Muslim personal law is excluded from the scrutiny of the Bill of Rights. The same argument applies to the meaning of "law" as contained in item 2(1) of schedule 6, which reads:

All law that was in force when the new Constitution took effect, continues in force, subject to -

(a) any amendment or repeal; and

(b) consistency with the new Constitution.

I do not agree with these viewpoints. It is inconceivable that there might be certain areas of "law" that are not subject to the scrutiny of the Bill of Rights. Such a viewpoint makes a mockery of the supremacy of the Constitution as emphasised in section 2 of the 1996 Constitution. Section 2 lays down that "any law or conduct" that is inconsistent with the 1996 Constitution is invalid and any obligations imposed by the Constitution must be performed. I submit that non-recognised Muslim personal law is indeed included in "all law" as contained in section 8(1) of the 1996 Constitution.

Own emphasis.

Burns Administrative Law 15.

De Waal Currie and Erasmus Bill of Rights Handbook 50.

See also Rautenbach and Malherbe Staatsreg 306. 
Such inference is supported, inter alia, by the text of the 1996 Constitution. Firstly, the use of "all law" in the 1996 Constitution in contrast to the use of "all law in force $^{117}$ in the 1993 Constitution, indicates that the constitutional drafters (perhaps?) envisaged that there could be law in South Africa that can not be classified as "law in force", but which nevertheless needed to be scrutinised in terms of the Bill of Rights. Muslim personal law would be a law system that is not in force, because it is not recognised in terms of South African law, but which needs to be scrutinised in terms of the Bill of Rights.

Secondly, section 2 of the 1996 Constitution recognises the supremacy of the 1996 Constitution and invalidates "law or conduct" that is inconsistent with the Constitution. It may, therefore, be argued that non-recognised Muslim personal law is "conduct" that is subject to the Constitution. The Bill of Rights forms part of the Constitution as a whole and therefore it can be argued that the Bill of Rights will also be applicable to conduct that is not law in terms of section 8 .

Thirdly, section 15 of the 1996 Constitution refers to "systems" of "religious, personal or family law". ${ }^{18}$ The use of the word "law" is a clear indication that the constitution writers saw these systems as systems of "law" and, therefore, it may be argued that "all law" in section 8(1) of the 1996 Constitution also refers to these law systems as "all law" that is subject to the Bill of Rights.

Fourthly, sections 30 and 31 of the 1996 Constitution, which recognise the religious and cultural diversity of the South African population, emphasise that religious and cultural rights must be exercised in a manner that is not inconsistent with any provision of the Bill of Rights. It does not make sense to say that Muslims have the right to enjoy their religion (which includes the Shari' $a$ ), but that the enjoyment of such a right that may lead to inequality before the law is not subject to the Bill of Rights because it is not included in the phrase "all law".

17 Own emphasis.

18 Own emphasis. 
A further argument that may be advanced for the inclusion of Muslim personal law in the phrase "all law" can be found in the viewpoint of Van der Vyver ${ }^{19}$ regarding the meaning of "law". He argues that "law" consists of both positive state law ("staatlike positiewe reg" as he calls it) and positive non-state law ("nie-staatlike positiewe reg" as he calls it). Positive state law includes legislation, custom and case law. On the other hand, positive non-state law includes, for example, the rules of a sports club or an organisation, or the rules of a family head laid down for the members of the family. ${ }^{20}$ If his argument were to be followed, it would mean that the rules of a religious group, such as Muslims, are positive non-state law that is "law" in terms of South African law.

Furthermore, numerous Acts in South Africa recognise certain aspects of Muslim marriages. For example, section 21(3) of the Insolvency $A c t^{21}$ describes the word "spouse" to include also a wife or husband married "according to any law or custom". In terms of section 31 of the Special Pensions $A c t^{22}$ a "dependant" includes the spouse of a deceased to whom he or she was married "under any Asian religion". A similar provision appears in the Demobilisation Act. ${ }^{23}$ In terms of section 1 of the said Act a "dependant" includes any surviving spouse to whom the deceased was married "in accordance with the tenets of a religion". Section 1(2)(a) of the Births and Deaths Registration $\mathrm{Act}^{24}$ includes in the term "marriage" all marriages concluded according to the "tenets of any religion". Although it may be argued that this legislation recognises Muslim marriages for practical reasons, it is indicative of the plurality of the South African society. It is therefore difficult to motivate why Muslim marriages are recognised for certain purposes, but not when the parties of a Muslim marriage turn to the courts for the recognition of their union. ${ }^{25}$

In spite of these arguments in favour of the inclusion of non-recognised Muslim personal law in the phrase "all law", it is not certain whether the courts would agree

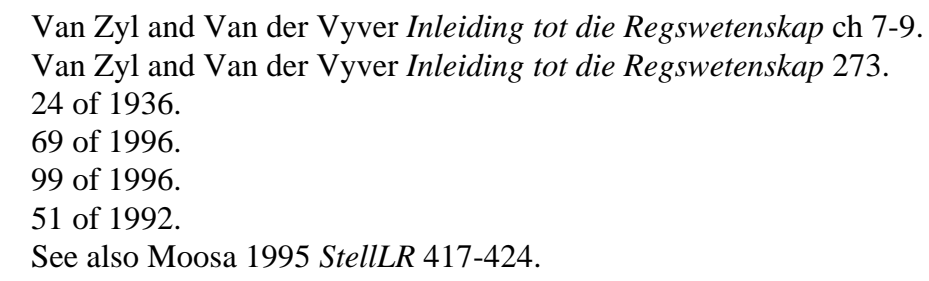


with this viewpoint. It is, therefore, recommended that recognition must be given to Muslim personal law, or at least to recognise Muslim marriages as valid marriages in South Africa.

Although the recognition of Muslim personal law or Muslim marriages falls outside the scope of this note it would be noteworthy to refer to two recent decisions regarding the validity of Muslim marriages. In Ryland $v$ Edros $^{26}$ the court was prepared to develop the common law to give recognition to the contractual consequences of a Muslim marriage in order to protect a Muslim wife who was divorced by her Muslim husband. Although this case is seen as a landmark regarding the rights of Muslims in South Africa, it is limited in three ways. Firstly, no recognition has been given to Muslim marriages. It is only the marriage contract, which arises from a Muslim marriage, that is recognised as valid. Secondly, the court did not deal with polygamous Muslim marriages and it is uncertain whether the court would have followed the same route if the marriage was in fact polygamous. Thirdly, it was a decision of the Cape Provincial Division and the possibility exists that other provinces might follow a different route because of the rule of stare decisis.

This was indeed what happened in Amod v Multilateral Motor Vehicle Accident Fund ${ }^{27}$ where the court refused to develop the common law in order to afford a claim for loss of support to a Muslim widow whose Muslim husband was killed in a accident. $^{28}$ Fortunately this decision of the Durban High Court was recently reversed by the Supreme Court of Appeal in Amod v Multilateral Motor Vehicle Accident Fund. $^{29}$ The Appeal Court developed the common law regarding a dependant's

2619971 BCLR 77 (C).

27199712 BCLR 1716 (D).

28 An Aquilian action for loss of support is at the disposal of a dependant of a breadwinner who was killed or injured as a result of the wrongful actions of another. This is referred to as the "action of a dependant". One of the requirements of the action for loss of support is that the breadwinner must have been under a common law duty to support his or her dependants. The courts have held, up to now, that such a "duty" arises from a relationship either from blood or a valid marriage. See Neethling Potgieter and Visser Law of Delict 283 et seq. Since a Muslim marriage is not regarded as a valid marriage in terms of South African law, the wife of a Muslim is not regarded as a dependant, and therefore, she may not institute a claim for loss of support if her husband is killed or injured. See Amod v Multilateral Motor Vehicle Accident Fund 199712 BCLR 1716 (D).

29 Case no 444/98 of 29.11.99. Published at http://www.law.wits.ac.za/sca/scadate.html 
action, without any reliance on the 1993 or 1996 Constitution, to afford a Muslim widow a claim for loss of support. The court held:

For the purposes of the dependant's action the decisive issue is not whether the dependant concerned was or was not lawfully married to the deceased, but whether or not the deceased was under a legal duty to support the dependant in a relationship which deserved recognition and protection at common law. ... On the analysis I have previously made she would indeed have such a right even if she was not validly married to the deceased in the civil law if the deceased was under a legally enforceable contractual duty to support her following upon a de facto monogamous marriage in accordance with a recognised and accepted faith such as Islam. ${ }^{30}$

Once again the effect of this case regarding the recognition of Muslim marriages is restricted to the following: it does not recognise the validity of Muslim marriages in general in South Africa, and it does not touch upon the action for support of a Muslim widow engaged in a polygamous Muslim marriage. ${ }^{31}$

\section{The meaning of "law" in the Constitution of India}

\subsection{Why the Constitution of India?}

There are various reasons why the provisions of the Constitution of India might be of value when interpreting provisions of the South African Constitution. Both countries were British colonies that received independence from Britain in the twentieth century. ${ }^{32}$ The English influence on various areas of the South African and Indian legal systems, such as the court system and criminal procedure, are still visible today. Other similarities between South Africa and India are their diverse multi-cultural and multi-religious societies. Furthermore, a large number of people in South Africa and

$30 \quad 27-30$.

31 For a further discussion of the argument in favour of the recognition of Muslim marriages in South Africa see Rautenbach "Recognition of Muslim marriages" 21 et seq.

32 For brief reference to the history of South Africa, see inter alia Boulle, Harris and Hoexter Constitutional and Administrative Law 117 et seq. 
India live according to usage and custom. $^{33}$ In India the various religious communities live according to their own personal law, such as Hindu law, Muslim law, Jewish law and so forth. Both countries have a minority Muslim population which lives according to a practice called Muslim personal law. Eleven and a half percent of the total population of India consists of Muslims. ${ }^{34}$ The majority of Muslims who first arrived in the former Cape Colony were brought from, inter alia, the coastal regions of Southern India as slaves, convicts and political exiles. ${ }^{35}$

Before British rule various personal laws were in force in India. Muslim personal law was applicable to Muslims, Hindu personal law was applicable to Hindus, Jewish personal law was applicable to Jews and so forth. During their rule the British followed a policy of non-interference with the personal laws of the local population. The result was the co-existence of various personal law systems in India. The policy of the government of India today is much the same and, although a substantial amount of legislation on some of the personal laws has been enacted, the various personal laws in existence in India are proof of this policy of the Indian government. ${ }^{36}$

\subsection{The meaning of law in terms of the Constitution of India}

As has been stated separate personal laws were applicable in India before the commencement of the Constitution of India. ${ }^{37}$ When the Constitution of India is studied, two questions arise, namely does the Constitution of India give recognition to the various personal laws in India and, if it does, is the Bill of Rights as contained in Part III of the Constitution of India applicable to these personal laws?

In contrast to the South African Constitution the Constitution of India does not require any special rules of interpretation and it must be interpreted like any other Act in operation in India. ${ }^{38}$ The purpose of interpretation is to determine the intention of

33 In South Africa the law of traditional communities are referred to as customary law.

34 De Reede 1996 Tilburg Foreign Law Review 145.

35 Moosa Muslim Personal Law 35 et seq.

36 Mahmood Statute-Law 10-12; Pearl Interpersonal Conflict of Laws in India 27-34; Diwan Family Law 2-3; The State of Bombay v Narasu Appa AIR 952 Bom 8487.

37 Mahmood Personal Laws in a Crisis 14-15; see also § 3.1.

38 Art 367(1) of the Constitution of India. 
the legislature. The purpose of interpreting the Constitution of India is, thus, to determine the intention of the constitution writers. ${ }^{39}$

In terms of article 372 of the Constitution of India "all the law in force" in India shall remain in force "until altered or repealed or amended". The phrase "law in force" has been interpreted by some to include the statutory and non-statutory law of India, which includes, inter alia, the various personal laws applicable in India. ${ }^{40}$ Mahmood $^{41}$ refers to various High Court decisions that accepted this outlook and argues that article 372 gives constitutional recognition to the personal laws in India.

However, in The State of Bombay v Narasu Appa Mali ${ }^{42}$ the High Court held that articles 372(1) and (2) do not refer to personal laws. In this case the validity of the Bombay Prevention of Hindu Bigamous Marriages Act ${ }^{43}$ was challenged. The Act prohibited polygamy between Hindus. The position regarding polygamy between Muslims was unaffected. It was argued that the Act infringed rights in terms of articles $14,{ }^{44} 15^{45}$ and $25^{46}$ of the Constitution of India. The court held that

... it is clear from the language of Arts. 372(1) and (2) that the expression "laws in force" used in this article does not include personal law because Art. 372(2) entitles the President to make adaptations and modifications to the law in force by way of repeal or amendment, and surely it cannot be contended that it was intended by this provision to authorise the President to make alterations or adaptations in the personal law of any community. ... [W]e have come to the conclusion that personal law is not included in the expression "laws in force."

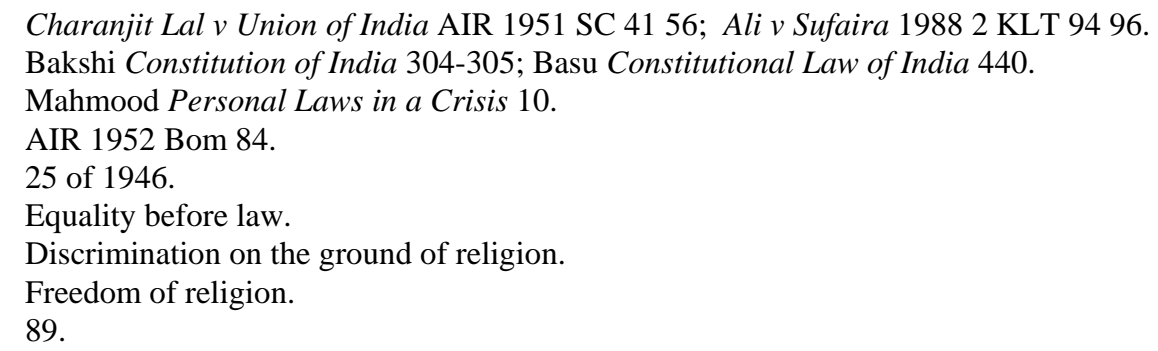


The viewpoint of the High Court in State of Bombay $v$ Narasu Appa Mali ${ }^{48}$ was criticised by various writers. Bhattacharjee ${ }^{49}$ referred to various supreme court decisions, where the phrase "all laws in force" has been used in a very wide and comprehensive manner as to include "statutory or non statutory, written or unwritten, customary or common, State-made or Judge-made" law. ${ }^{50}$ He assumes that the High Court referred to non-statutory personal law and argues that

... the non-statutory laws of the Hindus or the Muslims were obviously laws in the sense acceptable to modern Jurisprudence and [he] would like to think that no one would or can ever contend that the non-statutory personal laws of the Hindus or the Muslims were or are not such laws. ${ }^{51}$

However, it is clear from the facts of the case that the court held that personal laws (statutory or non-statutory) were not "law in force" in terms of article 372. The obvious question one should ask is then: if article 372 of the Constitution of India does not give constitutional recognition to the various personal laws in India, what then is the basis for its continuance in India today?

According to chief judge Chagla in The State of Bombay $v$ Narasu Appa Mali ${ }^{52}$ the Constitution of India gives indirect recognition to the relevant personal law systems in India. The court argued that article 44 of the Constitution of India recognises by necessary implication the existence and continuance of various personal law in India. Article 44 reads:

The State shall endeavour to secure for the citizens a uniform civil code throughout the territory of India.

Furthermore, article 246(2) of the Constitution of India empowers the Legislature to make laws regarding personal law matters. Article 246(2) contains the only reference

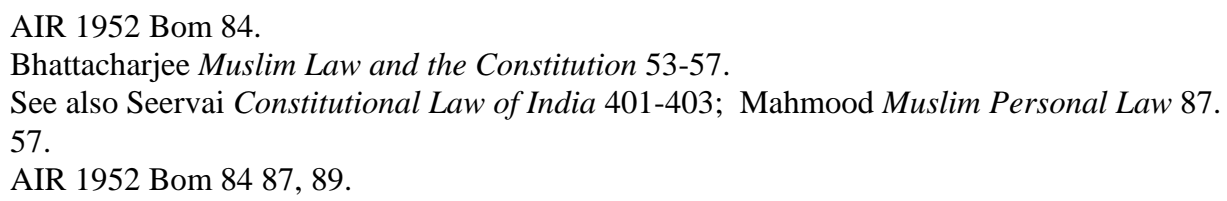


to personal laws in the text of the Constitution of India. In terms of this article the Parliament and legislatures of any State in India have the power, subject to certain limitations, "to make laws with respect to any of the matters enumerated in list III in the Seventh Schedule". Item 5 of list III includes the following matters:

Marriage and divorce; infants and minors; adoption, wills, intestacy and succession; joint family and partition; all matters in respect of which parties in judicial proceedings were immediately before the commencement of this Constitution subject to their personal law. ${ }^{53}$

In a concurrent but separate judgement judge Gajendragadkar ${ }^{54}$ agreed that item 5 of list III gives constitutional recognition to personal laws in India.

Although indirect constitutional recognition has been given to the various personal laws relevant in India, the application of the Bill of Rights as contained in Part III of the Constitution of India on these personal laws are a different matter. Part III of the Constitution of India contains a chapter on "fundamental rights" (hereinafter referred to as the Bill of Rights). Article 13(1), as contained in the Bill of Rights, lays down:

All laws in force in the territory of India immediately before the commencement of this Constitution, in so far as they are inconsistent with the provisions of this Part, shall, to the extent of such inconsistency, be void.

The extent of this article is limited in two ways. First of all it has no retroactive effect. The result is that all existing laws only become void from the commencement of the Constitution of India if they are inconsistent with the Bill of Rights. If any punishable acts were done before the commencement of the Constitution of India in contravention of any existing law, which is void in terms of article 13(1), such acts will still be punishable. ${ }^{55}$

53 Own emphasis.

54 State of Bombay v Narasu Appa Mali AIR 1952 Bom 84 90-91.

55 Keshavan Madhava Menon v State of Bombay AIR 1951 SC 128130.

P E R 1999 Vol 2 http://www.puk.ac.za/lawper/ 
Secondly, the Bill of Rights is not applicable to the various personal laws in India. This is indeed a strange phenomenon, which may largely be contributed to the interpretation of "law" in the Constitution of India. The term "law" is defined in terms of article 13(3)(a) to include "any Ordinance, order, bye-law, rule, regulation, notification, custom or usages having in the territory of India the force of law". The phrase "laws in force" is defined in terms of article 13(3)(b) to include "laws passed or made by a Legislature or other competent authority". The question, which has been described as a difficult one in Srinivasa Aiyar v Saraswathi Ammal, ${ }^{56}$ is whether personal laws are included in the term "law" and phrase "all laws in force". The court did not, however, think it necessary to decide the question.

The question was answered in the negative in State of Bombay v Narasu Appa Mali. ${ }^{57}$ The court rejected an argument that personal law is nothing more than custom and usage as defined in terms of article 13(3)(a) and held that

Custom or usage is deviation from personal law and not personal law itself ... the difference between personal law and custom is clear and unambiguous.

The court referred to section 112 of the Government of India Act of 1915, which refers to personal laws or customs having the force of law, and came to the conclusion that the words of section 112 clearly indicates that a distinction exists between personal law and custom. The court argued that the constitution writers had the wording of section 112 before them when they defined "law" in terms of article 13(3)(a), and the mere fact that they omitted personal law from the definition of "law" is an indication of the exclusion of "personal law from the purview of Art. 13".58

Furthermore, the court argued that articles $17^{59}$ and 25(2)(b $)^{60}$ of the Constitution of India, which deals specifically with certain aspects of Hindu personal law, are a clear

\footnotetext{
AIR 1952 Mad 193 195-196.

AIR 1952 Bom 8488.

88-89.

Abolition of untouchability.
} 
indication that personal laws in general were excluded from the operation of the Bill of Rights. Chief Justice Chagla held:

Now, if Hindu personal law became void by reason of Art. 13 and by reason of any of its provisions contravening any fundamental right, then it was unnecessary specifically to provide in Art. 17 and Art. 25(2)(b) for certain aspects of Hindu personal law which contavened Arts. 14 [equality before law] and 15 [discrimination on the ground of religion]. This clearly shows that only in certain respects has the Constitution dealt with personal law. ${ }^{61}$

Judge Gajendragadkar ${ }^{62}$ agreed that personal law is not "law" as defined in terms of article 13(3)(a). He based his viewpoint on another premise. According to him personal laws do not derive their validity from the fact that they have been enacted by means of legislation. On the contrary, personal laws are derived from "foundational sources" such as Muslim law that is derived from the Koran. He came to the conclusion that

... there can be no doubt that ... personal laws cannot be said to have been passed or made by a Legislature or other competent authority and do not fall within the purview of the expression "laws in force".

Another argument advanced by judge Gajendragadkar in favour of the exclusion of personal laws from the application of the Bill of Rights is article 44 of the Constitution of India. Article 44 compels the State to secure a Uniform Civil Code for all the citizens of India. According to judge Gajendragadkar article 44 is a direct result of the difficulties experienced by the various personal laws applicable in India. $\mathrm{He}$ is of opinion that the constitution writers recognised these difficulties and, therefore, they "refrained from interfering with the provisions of the personal laws" and instead they enacted article 44 to secure a Uniform Civil Code applicable to all the citizens of India. ${ }^{63}$

60 Throwing open of Hindu religious institutions to all Hindus.

6189.

62 State of Bombay v Narasu Appa Mali AIR 1952 Bom 84 90-91.

63 91-92. 
He referred to Item 5 of list III of Schedule 7 that recognises personal laws and said:

Thus it is competent either to the State or the Union Legislature to legislate on topics falling within the purview of the personal law and yet the expression 'personal law' is not used in article 13, because, in my opinion, the framers of the Constitution wanted to leave the personal laws outside the ambit of Part III of the Constitution. ... they did not wish that the provisions of the personal laws should be challenged by reason of the fundamental rights guaranteed in Part III of the Constitution and so they did not intend to include these personal laws, within the definition of the expression 'laws in force'. ${ }^{64}$

In Krishna Singh v Mathura Ahir ${ }^{65}$ the Supreme Court confirmed that the Bill of Rights as contained in part III of the Constitution of India "does not touch upon the personal laws of the parties". Since the Supreme Court is the highest court in India, its decisions are binding on all other courts lower in hierarchy. ${ }^{66}$

Various academic writers criticise the standpoint of the courts. Ghouse ${ }^{67}$ finds it difficult to see why personal laws are excluded from the scope of article 13(1). He agrees with Seervai ${ }^{68}$ who argues that the term "law" in article 13 should include personal laws.

However, due to the religious and cultural diversity of the Indian population, any attempt to apply the Constitution of India to the various personal laws is treated with suspicion. So far the various personal laws in India have escaped the scrutiny of the Constitution of India and the Bill of Rights as contained therein.

\section{$4 \quad$ Concluding remarks}

6497.

65 AIR 1980 SC 707712.

66 Jain Judicial system 134-135.

67 Ghouse Personal laws 57. 
Muslim marriages and Muslim personal law are not recognised in terms of South African common or constitutional law. The 1996 Constitution makes provision for the recognition of traditional and religious marriages and traditional and religious personal law systems by means of legislation. However, up to now, no legislation regarding religious marriages has been promulgated. In order to reach legal certainty regarding the application of the 1996 Constitution, legislative recognition should be given to Muslim personal law in South Africa. ${ }^{69}$

It must, however, be remembered that any legislation recognising Muslim personal law, or at least Muslim marriages, will have to stand the test of constitutionality before it will be accepted. $^{70}$ Furthermore, if the recognition is not acceptable to the Muslim community, the result will be mere paper law.

In contrast to the South African Constitution, the Constitution of India gives indirect constitutional recognition to the relevant personal laws in India. However, due to interpretation of articles 372 and 13 of the Constitution of India, personal law is not seen as "law" or "laws in force". The result is the non-application of the Bill of Rights as contained in Part III of the Constitution of India on matters dealing with personal laws.

The Constitution of India regarding personal laws differs from the South African Constitution in one important aspect. It does not contain a provision similar to section 15(3) of the 1996 Constitution of South Africa. Section 15(3) makes it clear that recognition of personal law systems based on religion "must be consistent with this section and the other provisions of the Constitution."

Although it is tempting to refer to the position in India regarding the recognition of personal laws and the interpretation of "law" as contained in the Constitution of India, such comparison must be done with caution. The relevant provisions of the

68 Seervai Constitutional Law of India 401-403.

69 An example of such legislation, although regarding customary marriages, is the Recognition of Customary Marriages Act 120 of 1998 (to be put into operation), which recognises polygamous customary marriages as valid marriages.

70 Section 15(3) of the 1996 Constitution. 
Constitution of India and the interpretation thereof do not serve as a good example of constitutional protection of rights within the personal laws sphere. One should approach the Constitution of India with caution when its provisions are compared to those of the 1996 Constitution of South Africa. 


\section{Bibliography}

Bakshi Constitution of India 304-305

Bakshi PM The Constitution of India (Universal Delhi1999)

Basu Constitutional Law of India 440

Basu DD Constitutional Law of India 6th ed (Prentice-Hall of India New Delhi1991)

Bhattacharjee Muslim Law and the Constitution 53-57

Bhattacharjee AM Muslim Law and the Constitution (Eastern Law House Calcutta 1994)

Boulle Harris and Hoexter Constitutional and Administrative Law 117

Boulle L, Harris B and Hoexter C Constitutional and Administrative Law: Basic Principles (Juta Cape Town 1989)

Burns Administrative Law 15

Burns Y Administrative Law under the 1996 Constitution (Butterworths Durban 1998)

Central Statistical Services Report 03/01/22 (91) Population Census 1991

De Reede 1996 Tilburg Foreign Law Review 145

De Reede J "The Muslims in India" 1996 Tilburg Foreign Law Review 145170

De Waal Currie and Erasmus Bill of Rights Handbook 50

De Waal J Currie I and Erasmus G The Bill of Rights Handbook 2nd ed (Juta Kenwyn 1999)

Diwan Family Law 2-3

Diwan P Family Law (Allahabad Law Agency Allahabad 1991) 
Ghouse Personal laws 57

Ghouse M "Personal laws and the Constitution in India" in Mahmood T (ed) Islamic Law in Modern India (NM Tripathi Bombay 1972) 50-58

Jain Judicial system 134-135

Jain SN "Judicial system and legal remedies" in Minattur J (ed) The Indian Legal System (Oceana Publications New York 1978) 133-147

Mahmood Muslim Personal Law 87

Mahmood T Muslim Personal Law 2nd ed (AIR Nagpur 1988)

Mahmood Personal Laws in a Crisis 14-15

Mahmood T Personal Laws in a Crisis (Metropolitan New Delhi 1986)

Mahmood Statute-Law 10-12

Mahmood T Statute-Law relating to Muslims in India (Institute of Objective Studies New Delhi 1995)

Moosa Muslim Personal Law 35

Moosa N An Analysis of the Human Rights and Gender Consequences of the New South African Constitution and Bill of Rights with regard to the Recognition and Implementation of Muslim Personal Law (LLM-thesis University of the Western Cape 1996)

Moosa 1995 StellLR 417-424

Moosa N "Muslim personal law: to be or not to be?" 1995 StellLR 417-424

Neethling Potgieter and Visser Law of Delict 283

Neethling J, Potgieter JM and Visser PJ Law of Delict 3rd ed (Butterworths Durban 1999)

Pearl Interpersonal Conflict of Laws in India 27-34 
Pearl D Interpersonal Conflict of Laws in India, Pakistan and Bangladesh (Stevens \& Sons London 1981)

Rautenbach "Recognition of Muslim marriages" 21 et seq

Rautenbach C "The recognition of Muslim marriages in South Africa: past, present and future" Paper delivered at the $17^{\text {th }}$ RIMO-symposium 18 June 1999 Leyden 21 et seq - to be published

Rautenbach and Malherbe Staatsreg 306

Rautenbach IM and Malherbe EFJ Staatsreg 2nd rev ed (Butterworths Durban 1996)

Seervai Constitutional Law of India 401-403

Seervai HM Constitutional Law of India: A Critical Commentary (NM Tripathi Bombay 1983)

Van Zyl and Van der Vyver Inleiding tot die Regswetenskap

Van Zyl FJ and Van der Vyver JD Inleiding tot die Regswetenskap 2nd ed (Butterworths Durban 1982)

\section{Cases}

Ali v Sufaira 19882 KLT 94

Amod v Multilateral Motor Vehicle Accident Fund 199712 BCLR 1716 (D)

Amod v Multilateral Motor Vehicle Accident Fund case no 444/98 of 29.11.99

Charanjit Lal v Union of India AIR 1951 SC 41

Du Plessis v De Klerk 19965 BCLR 658 (CC) 682

Keshavan Madhava Menon v State of Bombay AIR 1951 SC 128

Krishna Singh v Mathura Ahir AIR 1980 SC 707

Park-Ross v Director, Office for Serious Economic Offences 19951 SACR 530 (C)

Ryland v Edros 19971 BCLR 77 (C)

Srinivasa Aiyar v Saraswathi Ammal AIR 1952 Mad 193

The State of Bombay v Narasu Appa Mali AIR 1952 Bom 84 
Acts

Births and Deaths Registration Act 51 of 1992

Bombay Prevention of Hindu Bigamous Marriages Act 25 of 1946

Constitution of India

Constitution of the Republic of South Africa 108 of 1996

Constitution of the Republic of South Africa 200 of 1993

Demobilisation Act 99 of 1996

Insolvency Act 24 of 1936

Recognition of Customary Marriages Act 120 of 1998

Special Pensions Act 69 of 1996

\section{Internet}

The Supreme Court of Appeal of South Africa 1999 Amod v Multilateral Motor Vehicle Accident Fund case no 444/98 of 29/11/99 [Gevind op Internet] http://www.law.wits.ac.za/sca/scadate.html [Datum van gebruik Christa 1999] 